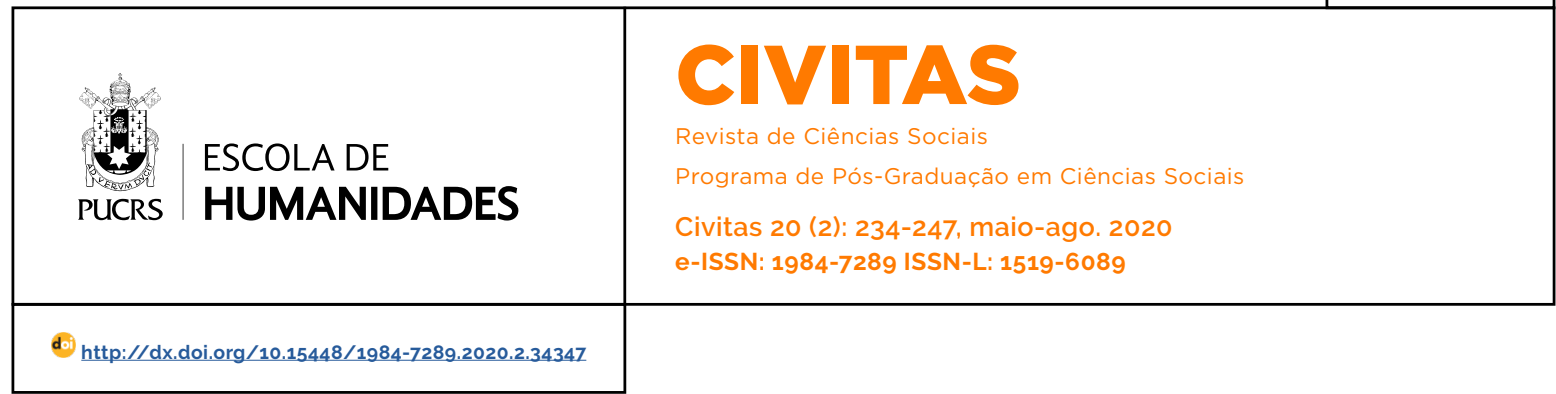

ARTIGOS/ARTICLES

\title{
The identity/alterity nexus in international relations: two cases of encounter with difference
}

\author{
O nexo identidade/alteridade nas relações internacionais: dois casos de encontro com \\ a diferença \\ El nexo identidad/alteridad en las relaciones internacionales: dos casos de encuentro \\ con la diferencia
}

\section{Erica Resende ${ }^{1}$ \\ orcid.org/0000-0001-5567-1635 ericaresendear@gmail.com}

Recebido em: 6 jun. 2019 Aprovado em: 22 out. 2019 Publicado em: 4 ago. 2020

\section{(c) (1)}

Artigo está licenciado sob forma de uma licença Creative Commons Atribuição 4.0 Internacional.
Abstract: The aim of this article is to survey the implications of the identity/alterity nexus in international relations (IR) as related to processes of othering for understanding conflict and violence in global politics. I will offer what I could call an ontology of difference in global politics, where I stress the reliance of understanding othering practices in global politics, as I explore two cases from which I ask the following questions: How do identity and identity formation processes occur and develop at different levels, times and dimensions? How do discourses of differentiation and identification help construct state identities and interests? Following Emmanuel Lévinas, I will argue that by seeking ways to reach out towards the Other, we free ourselves from the restraints of selfishness, from indifference and isolation. Finding and coming to terms with a composition of the Self that also includes the Other enables us to take responsibility for him/her inasmuch it prevents the conditions for violence and conflict. Keywords: Identity. Alterity. Discourses. Foreign policy.

Resumo: O objetivo deste artigo é pesquisar as implicações do nexo identidade/ alteridade nas relações internacionais (RI), relacionado aos processos de troca de ideias para a compreensão de conflitos e violência na política global. Oferecerei o que eu poderia chamar de ontologia da diferença na política global, onde enfatizo a confiança em entender outras práticas na política global, enquanto exploro dois casos dos quais faço as seguintes perguntas: Como ocorrem os processos de identidade e formação de identidade e se desenvolve em diferentes niveis, tempos e dimensões? Como os discursos de diferenciação e identificação ajudam a construir identidades e interesses do Estado? Seguindo Emmanuel Lévinas, argumentarei que, ao procurar maneiras de alcançar o Outro, nos libertamos das restrições do egoísmo, da indiferença e isolamento. Encontrar e chegar a um acordo com uma composição do Eu que também inclua o Outro nos permite assumir a responsabilidade por ele/ela, na medida em que impede as condições de violência e conflito. Palavras-chave: Identidade. Alteridade. Discursos. Política estrangeira.

Resumen: El objetivo de este artículo es examinar las implicaciones del nexo identidad/alteridad en las relaciones internacionales (RI) en relación con los procesos del otro para comprender el conflicto y la violencia en la politica global. Ofreceré lo que podria llamar una ontologia de la diferencia en la política global, donde enfatizo la dependencia de comprender otras prácticas en la política global, mientras exploro dos casos a partir de los cuales hago las siguientes preguntas: ¿Cómo ocurren los procesos de identidad y de formación de identidad y desarrollarse en diferentes niveles, tiempos y dimensiones? ¿Cómo ayudan los discursos de diferenciación e identificación a construir identidades e intereses estatales? Siguiendo a Emmanuel Lévinas, argumentaré que al buscar formas de alcanzar al Otro, nos liberamos de las restricciones del egoismo, de la indiferencia y el aislamiento. Encontrar y aceptar una composición del Ser que también incluye al Otro nos permite asumir la responsabilidad de él/ella en la medida en que evita las condiciones de violencia y conflicto. Palabras clave: Identidad. Alteridad. Discursos. Política exterior 


\section{Introduction}

The subject of the encounter, above all of the white European encounter, with unfamiliar cultures is a long story of violence and conflict. The world literature is full of examples in that regard: from Homer's Odyssey to The travels of Marco Paolo, from Joseph Conrad's Heart of darkness to EM Foster's A passage to India. They chronicle, narrate, depict, and represent the encounters between the Self and Other. Some end in a true conversation, where difference is embraced and celebrated at constituent features of humankind. Yet sadly, most feature stories of conquest, intolerance, and dominance. They often shape our common sense views of peoples and places, and instil in our minds stereotypes, prejudices, and phobias that usually inform the way we choose to engage with the Other. When the Other is represented positively, he is deemed as non-threating, hence maybe even an equal. If the depiction is negative, on the Other hand, he is taken as undeserving of recognition. Therefore, the way we chose to engage in our encounters with the Other carries an ethical consequence which is political.

As a result, issues of identity, difference, otherness, and alterity are especially relevant in current times for breaking away from recurrent cycles of violence and insecurity; trying to live in peaceful coexistence with others requires the acceptance of difference. Indeed, the debate on those key issues, specifically their impact on foreign and security policy, are very present in International Relations (IR) scholarship. Authors such as Neumann (1999), Houtum and Naerssen (2002), Diez (2005), Hansen (2006) and Reinke de Buitrago (2012; 2015) have generated insights about what is considered by some to be the subject of a broader Western metaphysical debate since Hegel (see Bernstein 1991, 68; and Neumann 1996a, 141).

However, a handful of questions still remain quite underexplored: How do identity and identity formation processes occur and develop at different levels, times and dimensions? How do discourses of differentiation and identification which reside at the core of othering practices help construct state identities, and co-constitute national interests? How do otherness and othering practices express themselves in foreign policy discourses, images, and popular culture? How could questions of tolerance, religion, collective memories, gender as well as feelings of solidarity, sympathy and empathy come into play in othering processes? If it is true that otherness could come in diverse forms and not only negatively, how could one maintain their own identity without producing barriers toward others? The aim of this article is to tackle some of those still somewhat underexplored questions in the hope of furthering the debate on the implications of identity formation, discourses of alterity, articulation of difference, and representations as related to processes of othering for understanding IR.

Beyond the academic debate of these issues, the study of identity, alterity and othering also comes with great societal and political significance. The creation and marking of difference and the drawing of borders carries conflict potential for international interactions among states, and for their societies. A more thorough understanding of such processes allows their critical reflection, as well as a reflection of the own role and of involved dynamics. Another possible contribution is to point to fruitful potential of adjusting political actions in a way so as to facilitate bridge-building rather than the creation of boundaries, and to interact with the Other so as to avoid harmful oppositions.

Following this introduction, four sections are presented and each raises a distinct question regarding the problem of otherness in IR. The first will feature a discussion about how we think about identity and difference. After surveying the traditional assumptions about identity and difference, and highlighting how othering processes influence and constitute violence and conflict, I will offer what I could call an ontology of difference in global politics, where I stress the reliance of understanding othering practices in global politics. The second section will feature two illustrative cases where dynamics of identity, discourses of difference, production of otherness, threat perception and threat articulation are intimately connected to identity construction 
processes as well as foreign policy choices. The third and final section will discuss the implication and consequences of othering practices in IR, as well as a call to an ethics of responsibility to the Other following Emmanuel Levinas' philosophy.

We will argue for the need for encountering the Other without the need to erect barriers of protection as a deluded self-defence mechanism of protecting and preserving own identity. Following Lévinas, I argue that by seeking ways to reach out towards the Other, we free ourselves from the restraints of selfishness, from indifference and isolation. Finding and coming to terms with a composition of the Self that also includes the Other enables us to take responsibility for him/her inasmuch it prevents the conditions for violence and conflict. In current times where life itself seems so fragile and tenuous, and where we continuously see the Other being reduced to less than human, this stands as an ethical imperative to all of us.

\section{Conceptualizing identity, difference, and otherness}

Traditionally, the discipline of International Relations (IR) has understood its object of study as the actions of states outside their national borders in a context of anarchy. Following this canonical rationale, especially within the inter-paradigmatic debate, the discipline has evolved perceiving its problématiques as pertaining to the nexus between war and peace, or conflict and cooperation (Guillaume 2011). However, especially since the mid-1980s and early 1990s, the discipline has gone through profound changes in understanding what IR is about. Inspired by the linguistic, sociological, critical, and aesthetic turns, many scholars have focused their attention towards issues of identity and processes of identity formation - in terms of states having national identities and or being the bearer of identity, and how national identities affect interstate relations (Holland 2013a; Neumann 1999).2 This shift has produced what Guillaume (2011) calls the identity/alterity nexus, which offers a new perspective to think about IR beyond the action of states outside their national borders.

In this sense, IR could be understood as the continuous process of constructing relations of Self and Other (Neumann 1996a; 1996b; 1999), or even the construction of difference (Nabers 2015), or furthermore an on-going process of converting difference into otherness. Discourses of alterity, which refer to the construction of the Other in juxtaposition to the Self, have frequently played a role in informing foreign policy. ${ }^{3}$ As Holland (2013b. 10-11, 24) and Shapiro (1989, 13-14) state, an identity's specific cultural foundation and its specific nationally oriented view also inform state behaviour. In addition, the analysis of international actors such as the European Union allows departing from the hierarchical, inward-looking and essentialist conceptions of identity that are typical for nation-states. Instead the EU provides a case study to reflect on more open-ended, fluid identifications in the global arena (Bretherton and Vogler 2006, 37), and to accentuate the possibility to overcome the pattern of negative othering that is characteristic for national identifications (Diez 2005; Neumann 1996b).

Broadly speaking, identity is the way in which we define ourselves in relationship to our surroundings, the world and others, and how we differentiate ourselves from others. It is not static, but somewhat stable, as it is part of the cognitive and emotional systems and formed early on. It may be defined in different ways in different circumstances, for example individual identity, group identity, or national identity. Identity construction begins in early childhood and in relation to socialisation and surroundings, hence a process. Yet, much of the identity remains relatively stable, once formed (see

\footnotetext{
2 Albeit identity could be placed under much of the canonical study of IR, especially if treated as a 'possible independent variable to explain war/conflict and peace/cooperation' (Guillaume 2011, 2), some studies demonstrate that perhaps identity could help expand the field of IR if taken more seriously (see Albert et al. 2001; Hansen 2006; Hansen and Waever 2002; Lynn-Doty 1993; Nabers 2009).

3 Additional theorizations of othering/otherness are found in Hansen (2006) and Herschinger (2011).
} 
Boulding 1996; Fisher 1997; Benwell and Stokoe 2006). ${ }^{4}$ It is constructed in difference to something other (Connolly 1991; Laclau and Mouffe 1985. 128). During this process of identity construction, the manner in which the Other is defined impacts identity in a process of co-constitution. That is, when the Other is portrayed or experienced as dangerous, the Self may feel threatened; when the Other is portrayed or experienced as non-threatening, the Self feels secure.

According to Münch $(2001,137)$, collective identity means "the attitudes, which all members of that group have in common in their thoughts and behaviour, which differentiates them from the "Other's". Therefore, identification implies "belonging or membership, which in turn implies the exclusion of non-members." (Bretherton and Vogler 1999, 236). According to Nabers (2015, 82), the logics of equivalence and of difference in processes of identification and differentiation between Self and Other point to the "constructedness of what appears to be a reality that is objective and timeless". Every social group is then constructed in an on-going practice of forming distinctions between us and them, Self and Other. Yet, otherness could come in diverse forms (Croft 2012, 91). If identity is constructed by both differentiating from and engaging with others (Lebow 2012, 270-271), it may be possible to maintain identity without producing harmful barriers toward others.

William Connolly talks about identity being constructed "on the shadow of the Other" (1991, $66)$ in the sense that it is established in relation to a series of differences that have become socially recognized by a group. They are essential to being, he argues, for if they did not coexist, identity would not have its distinctness and solidity. As a result, once confronted with difference, identity becomes unstable, unsecured, hence under powerful pressure to fix, regulate, or exclude the undesirable. "When this pressure prevails, the maintenance of one identity involves the conversion of some differences into otherness, into evil, or one of its numerous surrogates" (Connolly 1991, 64). As Campbell argues, any state that is speaking of itself as being threatened by another state creates difference towards the Other; the manner of threat articulation then shapes political processes (Campbell 1998a, 3, 171). Dirk Nabers highlights the instabilities inherent to any relational meanings, the threat of the inside by an outside, the dependence of the inside on differential relations within, and the infinite dispersion and constant presence of difference - "a whole cosmos of differences" (Nabers 2015, 100).

As suggested by Laclau (1996), identity is constituted based on relations of difference toward the Other, which in turn establishes the borders of the Self under construction. The Other must, necessarily, become the signifier for threat, chaos, instability and negativity in order to allow the articulation of the Self as the signifier for security, order, stability and positivity. As a result, in order to maintain and preserve a so-called cohesive national identity, there is a certain motivation to search for potential enemies, and states may thus easily perceive other states as threatening Others, which motivates the creation of otherness in IR.

Othering may be seen as process with multiple motivating factors. We should then better understand these factors and their interaction, as well as the specific points where othering is motivated, and what may be able to transform or end such a process. Ultimately, it is not every Other that mobilises the "we-feeling", and not every Other is framed in adversarial terms to the Self. The concept of significant Other then becomes useful in understanding the conflictual nature of othering but also the way in which the Other is productive in constructing the identity of agents (Morozov and Rumelili 2012).

We believe that current and past conflicts seem to evidence that othering is negatively biased, with

\footnotetext{
$4 \quad$ As correctly pointed out by one of the reviewers of this article, studies about the European Union enlargement show how ambiguous is the identity formation process. For example, in order to present themselves more positively, Eastern European states engaged in a discursive remaking of their own national identities - as victims of Soviet repression policies in the case of the Baltic states, as free market-oriented economies, or human rights sponsors. See Sedelheimer (2003) for the case of Slovakia, and Silva and Resende (2018) for the Baltic States. Both pieces stress the simultaneously fluid and conflictual quality of identity making process in the context of EU enlargement
} 
differentiation as well as distancing from the Other. There is thus further value in elucidating the question if othering is necessarily a negatively tainted process, that is, if the Other is always seen in a negative light. The academic debate diverges on this. For example, Diez (2005, 628-29) argues that the Other can also be seen as neutral. For Hansen (2006), however, there are always views of superiority and inferiority, thus hierarchy. For Bauman (2004), the binary opposition which lies at the base of this hierarchy is constantly subject to reversal.

Ways of perceiving the Other as both different and equal can be a worthwhile endeavour for the facilitation of balanced relations. There is great value in further defining the dynamics in multiple types of Self-Other relations, and the nuances involved in various types of othering processes. In order to illustrate our arguments, I will now explore two cases centred around issues of identity/alterity and how they pertain to specific security and foreign policy choices. The cases are: 1 ) the role of otherness in U.S. identity formation processes and foreign policy throughout time, and 2) the use of discourses of differentiation and identification in constructing Russian and European state identities.

\section{Illustrating difference and othering: two cases of othering in foreign policy discourses}

\section{Case 1: U. S. national identity, foreign policy and otherness}

According to Mansbach and Rhodes (2007. 444), politics has always harnessed national identities as the prime discourse for articulating, constructing and disseminating a kind of "marriage" between nation and state. This union has been responsible for creating a vehicle that simultaneously creates, reproduces and rationalizes a specific kind of polity that took dominance in modernity: the nation-state. A common identity gives people a sense of comfort - effective albeit also somewhat illusory - that their lives are connected and that they have a reason to act upon common interests and goals. Constructed and reproduced by discourse, the group becomes an imagined moral community (Anderson 1991) that defines itself and by inference what it is not: the Other. As a result, identity discourses articulate and construct a moral community which defines itself as "us" that is ultimately different from "them", the "them" being excluded from the collective. For these reasons, they are prescriptive for they have the capacity to create realities, subjectivities, and relationships between Self and Other, especially when they define which rights and duties are recognized for the members of the community but withheld from those outside it.

Let us take the United States of America as example. In his study of the Cold War, Campbell (1998a) observed that U. S. foreign policy texts of that time reproduced a very specific representation of reality. Articulations such "free and peaceful America" threatened by "an international conspiracy", set of values "granted by God" which are the roots of the "western civilization", among other representations, created a specific representation of what the American Self was. Identifying a sort of pattern in the production of difference between America/non-America, Campbell claimed that the constant and deliberate evocation of the "national mission", the "republic's objectives", the "defense of freedom", the "affirmation of the individual", and the "predestination of America" signaled that those policy documents did much more than simply offer an analysis of international politics: they reaffirmed a specific national identity for the United States: "Stamped 'Top Secret' and read by the elite, the texts blurred the lines between internal and external with 'quasi-puritan figurations'" (Campbell 1998a, 32).

Indeed, the discourse identified by Campbell remitted directly to what he claimed to be typically American puritan ideology. Narratives such as an "exceptional America" with the transcending "predestination" to be the "beacon of the world" and to act as "benign empire" - above all as opposed to the "Evil Empire" symbolized by the Soviet Union - seemed to serve foreign policy interests at the time. It indicated the attempt to script puritan ideology with the national, permanent and natural appearance. Employing 
the language, narrative, and style of the typical sermon of the puritans in Colonial America - the "jeremiad" 5 -, those texts signified the American Self as being ideologically puritan in opposition to the non-puritan Other (Bercovitch 1978; Campbell 1998a; Resende 2012).

This led Campbell to propose a relationship between ideology and U.S. foreign policy, whereby the use of discourse to signify "America" and "non-America" meant that foreign policy discourses construct and reproduce an essentialized, homogenized national American Self. According to him, foreign policy is then to be understood as the practice for constructing borders, since it discursively produces differences based on dichotomies such as inside/outside, domestic/ foreign, and friend/foe based on identity markers of specific ideological content.

Due to its incompleteness as a political project, the state engages in a process of permanent reproduction, seeking situations in which it becomes exposed to the outside/external/foreigner/Other in order to be able to reaffirm that which belongs to the inside/internal/national/Self. Through foreign policy, the privileged arena for contact with difference, the state employs discourses of fear to convert the external into a threat and thus reassure its moral and spatial borders, and to stabilize its own identity. Therefore, the constant articulation of danger through foreign policy is not a threat for the identity or the existence of the state, "but its possible condition" (Campbell 1998a, 13). By constantly articulating insecurity and creating otherness, the state seeks and constructs its own legitimacy.

Considering, however, that threats as well as the identities are never fixed, the state needs to continue to create and signify Others to legitimate its own reason for being. As a result, the discourse on the national Self occurs and develops at different levels, times and dimension, according to specific political and social contexts. Cullinane and Ryan's work on how the Other is constituted throughout U. S. foreign policy history presents a meaningful case. For them, alterity has frequently played a role in defining U. S. national interests for it simplifies and removes "the culture of its complexity, its position in historical time, place, and geographical location". The discourses that have constructed the American Other throughout time - from the Native Indian Other in colonial times to the British despotic rulers, from the Nazi Germans of World War II to the Soviet communists of the Cold War - do not seek to detail and understand other cultures; the effect is to produce a "simplified depiction of the Indian, the European, the Nazi, the Communist, and of Islam" (Cullinane and Ryan 2015, 2). And since those discourses are largely constructed and circulated within U. S. culture and its ideological sphere of influence, they end up sharpening American identity, placing it as morally superior to the inferior, undesirable, barbaric foreign Other. In this sense, U. S. foreign policy discourses are uniquely self-referential: a discourse articulated by Americans about America and Americans in opposition to non-America and non-Americans in a world full of danger and threats.

\section{Case 2: Russia and the European self/Other identity discourses}

Another way to understand the functioning of the identity/difference nexus in IR is to highlight the use of discourses of differentiation and identification in constructing state identities and interests. The first case, taken mostly from Neumann (1996b), emphasis is placed on how "multiple alien interpretations" of Europe "struggle, clash, deconstruct, and displace one another", taking language and discourses of difference seriously (Ashley 1987, 409; Der Derian 1987, 6970). Recognizing that identity is not located in "essential and readily identifiable cultural traits but in relations larticulated between Self and Other]", and that "the question of where and how borders towards the Other should be drawn

\footnotetext{
Adapted from Jeremiah's preaching in the Old Testament, the 'jeremiad' was a popular genre of public discourse in 1600 sassachusetts. Its key themes are the lamentation of the social decay, announcement of an impending doom, and exhortation to action for zeal and moral surveillance to assure salvation for the community. It has a strong tone of alert about the certainty and imminence of threats and danger at loom, which shall punish those who fell in sin, degeneration and moral vices. See Bercovitch (1975).
} 
therefore become crucial" (Neumann 1996b, 1), he shows how much Russia is caught between the attraction of an economically, politically and socially more developed Europe, and the appeal of being able to play an European style imperial role in less-developed Asia. Russians, by talking about Europe, also talk about themselves. Indeed, Russian interests in Europe are not postulated as objectively, natural, given national interests, but constructed by discourses "confined to Russian debates conducted, directed at Russians, concerning Europe and, by the same token, the Russian themselves" (Neumann 1996b, 2).

The process of delineating the European Other from the Russian Self is an active part of Russian identity formation. By engaging in discourses of differentiation and identification with Europe, Russian political debate is directed about how Russia conceives of and relates to Europe. Engaged in othering discourses that call a specific representation of Europe into being, the Russian public debate articulates a self-representation based on ideas about Europe. Europe is thus presented as a speech act for it is talked about and written into existence by Russian intellectual and political debate throughout time. As a result, the Russian debate about Europe is also a debate about what Russia is and should be, and how it should act in the world in terms of policy, he concludes.

Neumann revisits the last two hundred years, starting at the time of the French and Industrial Revolutions, up until the collapse of the Soviet Union in 1991. For Neumann, war and change in the top leadership stand out as key moments for the intensification of discourses of differentiation and identification. The French Revolution and the Napoleonic Wars are taken as the starting temporal mark for the Russian debate about Europe. The overthrow of what had been considered the natural social order - enlightened absolutism, which then became the ancien Régime - led to a widespread debate about legitimacy, democracy and rule, which transcended France. Three main positons emerged as Russian reaction: a conservative nationalist trend, represented by the state, interpreted the French Revolution as a betrayal of monarchical ideals, hence the option for Russia was to carry on as before and pursue an isolationist albeit not confrontational policy towards Europe. A Romantic nationalistic trend, much influenced by German Romanticism, was anti-modern, Christian Orthodoxy-based, and thus against what had been perceived as the "estatisation and bureaucratization of the Tsar's rule" (Neumann 1996b, 13), which resulted in the rejection of French culture - including the use of French language by the elites - and the positioning of Russia as a morally superior society due to its status as "true Europe" as opposed to the "false Europe" of revolutionaries. The third trend adopted a more constitutionalist position, advocating that the political and economic models born out of the Twin Revolutions should be adopted and adapted to Russia.

The trends identified above would engage in an on-going debate for the next several decades and well into the twentieth century as Russia underwent several crisis where Russian national identity became less stable and hence more contested. Wars and changes in leadership such as the 1825 Decembrist Uprising, the Bolshevik Coup of 1917, the Polish-Russian War (1919-1921), the World War I and II, the de-stalinization process following Josef Stalin's death in 1953, the ousting of Khrushchev in 1964, and the 1980 s Glasnost and Perestroika reforms provided the fitting atmosphere for the debate about Europe - and about Russia's position vis-à-vis Europe - to emerge.

With the collapse of the Soviet Union in 1991, Neumann sees different proposals for the relationship between Russia and Europe, all risen from different moral assessments. Liberals have always regarded Europe as either morally superior to Russia, if viewed synchronically, or morally equal, if viewed diachronically. They tend to see Russia as steadily developing along the same lines as Europe. The proposed course of action of foreign policy would then be of apprenticeship or partnership that favors cooperation between the two. This was initially the assessment made by Russian under Yeltsin, Neumann argues (1996b, 200), when Russia was represented to be similar 
to Europe, albeit moving slower and less subtle towards liberals ideals of democracy, free economy, and rule of law. A xenophobic one stresses defense and struggle against the sudden Western "occupation" of a new Russia after the Cold War (Neumann 1996b, 197).

Albeit in constant flux, one discursive position is identified as a fixture: the position of the state. It calls upon itself to determine the limits of public debate, and it directs power resources toward the debate itself, employing multiple strategies to control the debate. Fine examples are the use of censorship, the withholding of records and information, the investment in publication channels such as official newspapers, television and radio stations. The state gives incentives to specific narratives and representations by selecting which debate participants should be punished or rewarded. As a result, the Russian state not only defines the limits of the political debate, but places its own position at the center, thus becoming a fixture in discourse.

For Neumann, the Russian state has privileged two distinct models for Russians to identify with. During the 1800s, the Russian state represented itself as "true Europe" in opposition to the scenario where the rest of Europe had turned away from the values of the anciens régimes. During the 1900s, it opted for representing itself as "true Europe", while the rest of Europe had failed to adopt the values of socialism (Neumann 1996b, 194). During the Cold War, not surprisingly, the debate intensified and followed the well-known patterns of enemy images, sharpening East and West conceptions as existential opposites.

As Neumann demonstrates, the Russian debate about Europe generates, diffuses and transforms ideas about Russia's own political project within the public space controlled by the Russian state. In discussing Europe, Russians have also clearly been discussing themselves and hence talking themselves into existence as they differentiate or identify with Europe's political projects through time. Neumann's account has the merit of formulating a critique of neo-realist insights about the state system. Kenneth Waltz's claim that competition produces tendency toward sameness of competitors (Waltz 1979, 127) resulted in a theory of international relations that does not offer an ontology of the state. Indeed, he has little to say about how the modern state system came about (see Ashley 1984). Neumann's study shows how Russians have interpreted and acted upon to implement this competition.

\section{Implications and consequences of othering practices}

Othering may be seen as process with multiple motivating factors. As scholars point out, the articulation of threats should be paid attention to, for once risks, threats and dangers have been articulated, their constitutive and long-lasting effects tend to persist; dichotomies and boundaries between Self and Other are produced and reproduced in discourse and become part of policy processes and structures that in turn inform ensuing interpretation and behaviour towards the Other (Holland 2014). Current and past conflicts evidence othering being negatively biased, with differentiation and distancing from the Other. If this is necessarily so it must be still elucidated.

Yet, if identity is constructed by both differentiating from and engaging with Others (Lebow 2012, 270-271), it may be possible to maintain identity without producing harmful barriers toward Others. Ways of perceiving the Other as both different and equal can be a worthwhile endeavour for the facilitation of peaceful relations. For if otherness could come in diverse forms and not only from negative differentiation, how could a person, a group and a state's society maintain their own identity without producing harmful barriers toward Others? Some argue that identity formation is not only a process of differentiation from Others but also one of moving towards Others, making it then possible to form identity without the building of barriers towards Others (Lebow 2012, 270-271); the direction it takes likely depends on existing conditions of Self-Other relations and factors of influence. Scholars also see the possibility of otherness taking distinct, multiple forms (Croft 2012, 91) or of othering being neutral and not only negative (Diez 2005, 628-29). 
If there is a chance for this, there is the possibility and chance for neutral or positive differentiations between Self and Other, or a form of differentiation that does not result in creating an, in whatever form or degree, threatening Other. Thus, if identity may be maintained without building harmful oppositions, there must not be a negative process of creating otherness or othering.

How may it be/become possible to see and experience difference to the Self in a neutral or even in a positive way? Following Emmanuel Levinas, I propose that this encounter could occur through a dialogue that prevents barriers of protection as a self-defence mechanism of protecting and preserving one's own identity. At the core of Levinas' philosophy are descriptions of the encounter with the Other: the Other impacts me unlike any worldly object or force. I can constitute the other person cognitively, on the basis of vision, as an alter ego. I can see that another human being is "like me", and acts "like me". As a result, subjectivity is born out of its relations to Others (Levinas 1985, 96), and the responsibility that derives from this encounter (Levinas 1966, 41) for the "being-for-the-other" also defines who we are. In this sense, subjectivity is primordially ethical as responsibility for the Other and is not a derivative feature of our subjectivity, but instead its anchor, as it gives it meaningful direction and orientation (see also Peperzak 1993; Burggraeve 1999; Bergo 2017).

Levinas derives the primacy of his ethics from the encounter with the Other, which he calls the face-to-face. For Levinas, the Other is not knowable and cannot be made into an object of the Self, as is done by traditional ontology. Responsibility toward the Other precedes any "objective searching after truth". The experience of the face-to-face constitutes a privileged phenomenon in which both the Other's proximity and distance are strongly felt. "The Other precisely reveals himself in his alterity not in a shock negating the I, but as the primordial phenomenon of gentleness" (Levinas 1969, 151).

He goes on to argue that the encounter of the Other through the face-to-face experience forbids any attempts to exclude, domesticate, or reduce to sameness, and simultaneously installs the responsibility for the Other in the Self. Here the connection between responsibility and the Other becomes the basis for Levinas' ethics: to be responsible means to make oneself available for service to the Other so that one's own life is intrinsically linked with the Other's life (Levinas 1985. 97). I am thus a human being in the sole measure that I am responsible for another. Responsibility becomes then the "place where I bind myself to the Other" (Levinas 1981, 12). Rather than the binding of a piece of material to the block of which it is a part, nor as organ to the organism in which it functions (Levinas 1966, 41), it is the place in which the Self enters into a relationship that is disinterested, but not indifferent, with the Other. Responsibility seeks the good of the Other, not looking for recognition in the Other. Thus, the desire for the Other is not appetite but generosity (Levinas 1966, 39). Being-for-itself means that the Self is pre-occupied with itself, and therefore, indifferent to the Other (Levinas 1969, 87).

Levinas' term "being-for-the-Other" (Levinas 1969, 261) indicates a position in which the Self is responsible for the Other, which requires the exercise of sensibility (Levinas 1981, 77), one that implies exposure or being in proximity to the Other. It involves standing in the place of another and offering protection to them (Levinas 1969, 135-136). Therefore Levinas' ethics of alterity consists in opening one's Self to the Other, especially the one that is different, unequal, diverse, and plural, which deserves to be respected as it is, without indifference, dismissal, repulsion, exclusion, or simplification of its particularities. Only by embracing a conception of the Self that also includes the Other will we be able to let go of restraints of selfishness, indifference and isolation. After all, we are in some degree dependent on the Other inasmuch our sense of Self emerges from encountering the Other: we are constituted in and by our relationship to it.

Levinas' ethics of otherness was first introduced into IR via three major themes: the ethics of responsibility in genocide, the unintentional violence in knowledge production, and the con- 
cept of hospitality in forced displacement. Writing about the war in Bosnia, David Campbell used Levinas' philosophy to rethinking the question of responsibility, especially in context of ethnic cleansing like Bosnia (see Campbell 1994; 1998b). Arguing that responsibility is not a choice but an ethical imperative, Campbell wrote that the international community was required to stop and listen to the voices within Bosnia that were not oriented toward nationalism and/or partition, and to consider those Others who were advocating non-nationalist paradigms as potential partners in a multicultural peace process. Levinas' concern over the ethics of responsibility has inspired authors such as Elizabeth Dauphinee and Michael Shapiro to focus on how knowledge systems contribute toward unintentional violence in IR scholarship. While Shapiro (1999) points out that IR itself constitutes an enclosed system of beliefs that undermine alternative possibilities for how we might understand and approach the world, Dauphinee (2007) has argued that knowledge produced by researchers about post-conflict societies involves a rapid categorization of "good" and "evil", which undermines responsibility in Levina's sense, for it suggests that the "good" are the only group to which we are obligated. Finally, Roxanne Lynn-Doty (2006) has evoked Levinas' notion of responsibility in her work about Latin American migrants crossing the deserts into the $U$. S. She points out that organizations such as Fronteras Compasivas enact Levinas' ethics of hospitality in their political practice. By building and maintaining life-saving water reserves in the desert, Fronteras Compasivas acts with responsibility towards the Other, for they will never know the names, legal status, or identities of those who will rely on their water reserves to survive their deadly journeys. In common, this scholarship is concerned with understanding the new dilemmas for responsibility in terms of the need to identify to whom we are responsible in our political practices. In short, what does it mean for political practices to find ourselves infinitely obligated to Others? Levinas thinking opens us up to a responsibility equally radical as inescapable that it compares to a hos- tage situation: "I am pledged to the other without any possibility of abdication. I cannot slip away from the face of the other in this nakedness...to approach is to be the guardian of one's brother; to be the guardian of one's brother is to be his hostage" (Levinas 1998, 72).

Going back to the two cases explored in this essay, the dominant narratives of both Russia and U. S. foreign policy evoke examples of how expectations about the encounter with difference affect othering construction processes. Levinas' idea of responsibility stems from the awareness that our very existence always generates violence, whether we mean it or not. Our comfortable lives are always made possible by another's suffering, even when we do not wish this outcome. It is our existence itself that causes potential injury to the Other for we are always dependent on the Other for our very sense of Self - be it the American, Puritan sense of Self, or the Russian non-European Self. Ultimately, we are constituted in and by our relationship with the Other, and this this relationship is not based on expectations, on universal rights, on community or family ties, or even on national loyalty. In short, we are unconditionally responsible for the lives of Others, and this is the command that our living together in a world of difference presents to us.

\section{Concluding remarks}

This article has attempted to explore what I perceive as the ultimate challenge of our times: How can we live together peacefully in a world that is made of difference? This question leads us to engage with the politics of otherness, that is, to understand how the identity/alterity nexus impact on issues regarding collective identity formation and difference, but as well as to reflect upon our own responsibility regarding the life of the Other.

After presenting a brief survey about the ways I conceptualize identity and difference in IR, and the consequences of the way we think about them, I advanced my argument by exploring two cases that feature the role of othering in security and foreign policy choices. Taken together, they pointed to how national identity and identity formation 
processes occur and develop at different levels, times and dimensions, and how do they relate to foreign policy and threats. I have also highlighted the importance of discourses of differentiation and identification in constructing state identities and interests. I have shown how otherness and othering practices express themselves in foreign and security policy discourses, narratives, images, and popular culture.

But perhaps this is also a question of matters relating to some level of equality or comparability of abilities and wealth/material security, since humans tend to compare themselves with groups and individuals around themselves. Comparing between Self and Other seems to be a key mechanism for understanding the Self vis-à-vis Others around. Thus, groups that find a somewhat comparable level of wealth in groups surrounding them have one strong motivation less on which to differentiate themselves against Others in a negative manner. But seeing difference neutrally or positively would also seem to be a question of - more or less cultivated - ability of living with difference without needing to judge as better or worse, in a way that difference itself is perceived as less strong or even marginal, as being of little relevance to the safety and security of the Self, thus not serving or being used as motivation to treat others or act towards others in a divisive manner.

In a way, this is a societal task, and an essential one for peaceful relations in our world. But the smallest unit of any society is the individual, and any individual finds itself in the unit of the family; it is in families where socialization of all members of society begins, where the foundation is laid for later thinking and behaviour. Families then also play a pivotal role in how difference between Self and Other is perceived, experienced and acted upon. In fact, it is in families that children, at a very young age, learn - physically and psychologically - to comprehend themselves as unique beings, separate from others, yet also in many ways being similar to others, as well as how to communicate with and behave toward others. Key in such processes is also how parents, but also grandparents and older siblings, teach how to deal with (various types of) difference by acting toward (various) others. As known, difficulties in relations with others as well as pathological or "ineffective" ways of dealing with these are often transferred to children, who then apply similar modes of behaviour. Family is then a key location of teaching about Self-Other difference and deserves much greater focus when it comes to how difference can be dealt with in a neutral or even positive manner.

Another focus may be the role of teaching not only tolerance of difference but, even more, the seeing of difference as enrichment and enjoyment, as something desired and desirable - thus, as truly positive. Such efforts seem existentially important when viewing the global landscape of recurrent conflict and distress. This should begin also in the family, but then be continued in kindergartens and schools (and there are plenty of examples where teachers work towards an inclusive view of difference). There is certainly room for this at the workplace too; how to deal with diversity in a positive manner is in fact of interest for increased productivity, thus in actual monetary terms, but also regarding the creation of a positive work climate. Moreover though, it is political actors who need to recognize that their often instrumentalized use of difference, for various political agendas, is harmful for societal and international relations, causing much greater costs in the middle and long term than bringing hope for gains in the short term. ${ }^{6}$

The main point here, following Levinas' ethics of responsibility, is not to judge the Self as morally right or intentionally violent for the Other will always be harmed despite our best intentions. Rather we should practice a "guiltless responsibility" (Levinas 1989, 83) considering that the Self is always hostage to the Other due to the notion of ethics as the first philosophy according to Levinas. Ethics is the prior condition on which

\footnotetext{
6 As pointed out by one reviewer, the question of how the role of teaching and family is interplayed within the nation-state and its processes of identity and otherness in Levinas's philosophy remains open in this article. Indeed, theorizing the possibilities for transition from ethics to politics is a true challenging aspect of Levinas' thinking. As noted by Patricia Malloy, this passage is a "bumpy ride" (Molloy 1999 , 233), and I consciously avoid doing it here due to the limitation of this article in terms of scope and length.
} 
all subsequent philosophy is built, therefore all ethical thought finds its source in our continuous, unconditional, and infinite responsibility to and for the Other. As a result, our very being is tied to the protection of the Other for this is what it means in ethical terms when we argue that Self and Other are mutually constituted. In this sense, it is always helpful to remember Levinas' favourite quote from Dostoyevsky's The Brothers Karamazov: "We are all responsible for everyone else - but I am more responsible than all the others". By taking responsibility for the Other, we also reject the possibility of violence that could emerge from an encounter with the Other, especially when acts of violence are committed and justified in relation to the so-called protection of a specific Self from a dangerous, threating Other. In current times, where life itself seems so fragile and tenuous, and where we continuously see the Other being reduced to less than human, this stands as an ethical imperative to all of us.

\section{References}

Albert, Mathias; Yosef Lapid, and David Jacobsen (eds.). 2001. Identities, borders, orders. Rethinking international relations theory. Minneapolis: University of Minnesota Press.

Anderson, Benedict. 1991. Imagined communities. Reflections on the origin and spread of nationalism. London: Verso.

Ashley, Richard. 1984. The poverty of neo-realism. International Organization 38 (2): 225-286. https://doi. org/10.1017/So020818300026709.

Ashley, Richard. 1987. The geopolitics of geopolitical space: toward a critical social theory of international politics. Alternatives 12: 403-434. https://doi. org/10.1177/030437548701200401.

Bauman, Gerd. 2004. Grammars of identity/alterity: a structural approach. In Grammars of identity/alterity: a structural approach, edited by Gerd Bauman, and André Gingrich, 18-23. New York: Berghahn.

Benwell, Bethan, and Elizabeth Stokoe. 2006. Discourse and identity. Edinburgh: Edinburgh University Press.

Bercovitch, Sacvan. 1975. The puritan origins of the American self. New Haven: Yale University Press.

Bercovitch, Sacvan. 1978. The American jeremiad. Madison: University of Wisconsin Press.

Bergo, Bettina. 2017. Emmanuel Levinas. In The Stanford Encyclopedia of Philosophy Archive, edited by Edward N. Zalta. https://plato.stanford.edu/archives/fall2017/ entries/levinas/, accessed Oct. 3, 2017.
Bernstein, Richard J. 1991. The New constellation: the ethical-political horizons of modernity/postmodernity. Cambridge: Polity.

Boulding, Kenneth E. 1996. National images and international systems. In Culture, communication and conflict: readings in intercultural relations, edited by Gary R. Waever, 459-470. Needham Heights-MA: Simon \& Schuster Custom Publishing.

Bretherton, Charlotte, and John Vogler. 1999. The European Union as a global actor. London: Routledge.

Bretherton, Charlotte, and John Vogler. 2006. The European Union as a global actor. 2 ed. London: Routledge.

Burggraeve, Roger. 1999. Violence and the vulnerable face of the other: the vision of Emmanuel Levinas on moral evil and our responsibility. Journal of Social Responsibility 30 (1): 29-45. https://doi.org/10.1111/00472786.t01-1-00003.

Campbell, David. 1994. The deterritorialization of responsibility: Levinas, Derrida and ethics after the end of philosophy. Alternatives 19: 455-84. https://doi. org/10.1177/030437549401900402.

Campbell, David. 1998a. Writing security. United States foreign policy and the politics of identity. Revised edition. Minneapolis: University of Minnesota Press.

Campbell, David. 1998b. National deconstruction: violence, identity, and justice in Bosnia. Minneapolis: University of Minnesota Press.

Connolly, William. E. 1991. Identity/difference: democratic negotiations of political paradox. Minneapolis: University of Minnesota Press.

Croft, Stuart. 2012. Securitizing Islam: identity and the search for security. Cambridge: Cambridge University Press.

Cullinane, Michael Patrick, and David Ryan Ryan, eds. 2015. U. S. foreign policy and the Other. New York: Berghahn.

Dauphinee, Elizabeth. 2007. The ethics of researching war: looking for Bosnia. Manchester: Manchester University Press.

Der Derian, James. 1987. On diplomacy: a geneology of Western estrangement. Oxford: Blackwell.

Diez, Thomas. 2005. Constructing the self and changing others: reconsidering "normative power Europe". Millennium. Journal of International Studies 33 (3): 613636. https://doi.org/10.1177/03058298050330031701.

Fisher, Glen. 1997. Mindsets: The role of culture and perception in international relations. 2 ed. Yarmouth: Intercultural Press Inc.

Guillaume, Xavier. 2011. International relations and identity: a dialogical approach. London: Routledge.

Hansen, Lene and Ole Waever, eds. 2002. European integration and national identity: the challenge of the Nordic states. London: Routledge.

Hansen, Lene. 2006. Security as practice: discourse analysis and the Bosnian war. Oxon: Routledge. 
Herschinger, Eva. 2011. Constructing global enemies: hegemony and identity in international discourses on terrorism and drug prohibition. London: Routledge.

Holland, Jack. 2013a. Foreign policy and political possibility. European Journal of International Relations 19 (1): 49-68. https://doi.org/10.1177/1354066111413310.

Holland, Jack. 2013b. Selling the war on terror: foreign policy discourses after 9/11. London: Routledge.

Holland, Jack. 2014. The elusive essence of evil: constructing Otherness in the coalition of the willing, In Arguing counterterrorism: new perspectives, edited by David Pisoiu, 201-220. Routledge Critical Terrorism Studies. New York: Routledge.

Laclau, Ernesto. 1996. Emancipación y diferencia. Buenos Aires: Ariel.

Laclau, Ernesto and Chantal Mouffe. 1985. Hegemony and socialist strategy. Towards a radical democratic politics. London: Verso.

Lebow, Richard Ned. 2012. The politics and ethics of identity: in search of ourselves. Cambridge: Cambridge University Press

Levinas, Emmanuel. 1966. On the trail of the Other. Philosophy Today 10 (1): 34-45. https://doi.org/10.5840/ philtoday19661014.

Levinas, Emmanuel. 1969. Totality and infinity: an essay on exteriority. Dordrecht: Kluwer Academic Publisher.

Levinas, Emmanuel. 1981. Otherwise than being or beyond essence. The Hague: Nijhoff.

Levinas, Emmanuel. 1985. Ethics and infinity. Pittsburgh: Duquesne University Press.

Levinas, Emmanuel. 1989. The Levinas reader. Edited by Sam Hand. Oxford: Blackwell.

Levinas, Emmanuel. 1998. Of God who comes to mind. Bergo: Stanford University Press.

Lynn-Doty, Roxanne. 1993. Foreign policy as social construction: a post-positivist analysis of U. S. counterinsurgency policy in the philippines. International Studies Quarterly 37 (3): 297-320. https://doi. org/10.2307/2600810.

Lynn-Doty, Roxanne. 2006. Fronteras compasivas and the ethics of unconditional hospitality. Millennium: Journal of International Studies 35 (1): 53-74. https://doi. org/10.1177/03058298060350010701.

Mansbach, Richard, and Edwards Rhodes. 2007. The national state and identity politics: state institutionalisation and "markers" of national identity. Geopolitics 12 (3): 426-58. https://doi.org/10.1080/14650040701305633.

Molloy, Patricia. 1999. Face to face with the dead man: ethical responsibility, state-sanctioned killing, and empathetic impossibility. In Moral spaces: rethinking ethics and world politics, edited by David Campbell, and Michael Shapiro, 467-492. Minneapolis: University of Minnesota Press.
Morozov, Viatcheslav, and Bahar Rumelili. 2012. The external constitution of European identity: Russia and Turkey as Europe-makers. Cooperation and Conflict 47. (1): 28-48. https://doi.org/10.1177/0010836711433124.

Münch, Richard. 2001. Nation and citizenship in the global age: from national to transnational ties and identities. New York: Palgrave Macmillan.

Nabers, Dirk. 2009. Filling the void of meaning: identity construction in U. S. foreign policy after September 11, 2001. Foreign Policy Analysis 5 (2): 191-214.

Nabers, Dirk. 2015. A poststructuralist discourse theory of global politics. New York: Palgrave Macmillan.

Neumann, Iver B. 1996a. Self and Other in International Relations. European Journal of International Relations 2 (2): 139-74

Neumann, Iver B. 1996b. Russia and the idea of Europe: a study in identity and International Relations. London: Routledge.

Neumann, Iver B. 1999. Conclusion: Self and Other after the death of the sovereign subject. In Uses of the Other. "The East" in European identity formation, edited by Iver B. Neumann, 207-228. Manchester: Manchester University Press.

Peperzak, Adriaan. 1993. To the Other: an introduction to the philosophy of Emmanuel Levinas. West Lafayette: Purdue University Press.

Reinke de Buitrago, Sybille, ed. 2012. Portraying the Other in International Relations: cases of othering, their dynamics and the potential for transformation. Newcastle upon Tyne: Cambridge Scholars Publishing.

Reinke de Buitrago, Sybille. 2015. Self-Other constructions, difference and threat: U. S. and Arab "othering" of Iran. In Regional insecurity after the Arab Uprisings, edited by Elizabeth Monier, 85-106. New York: Palgrave Macmillan.

Resende, Erica Simone Almeida. 2012. Americanidade, puritanismo e política externa. Rio de Janeiro: Contracapa.

Sedelmeier, Ulrich. 2013. EU enlargement, identity and the analysis of European foreign policy: identity formation through policy practice. EUI Working Papers, RSC n. 2003/13, European Forum Series.

Shapiro, Michael J. 1989. Textualizing global politics. In International/intertextual relations: postmodern readings of world politics, edited by James Der Derian, and Michael Shapiro, 11-22. New York: Lexington Books.

Shapiro, Michael J. 1999. The ethics of encounter: unreading, unmapping the imperium. In Moral spaces: rethinking ethics and world politics, edited by David Campbell, and Michael Shapiro, 57-91. Minneapolis: University of Minnesota Press.

Silva, Graziela Dumard da e Erica Simone Almeida Resende. 2018. Entre a Rússia e a União Europeia: os paises bálticos e o desafio da reconstrução das identidades nacionais após o colapso da União Soviética. Curitiba: Appris.

Waltz, Kenneth. 1979. Theory of International Relations. Reading: Addison-Wesley. 


\section{Erica Simone Almeida Resende}

Doutora em Ciência Política, com ênfase em Relações Internacionais, pela Universidade de São Paulo (USP), São Paulo, SP, Brasil. Professora Adjunta de Relações Internacionais da Escola Superior de Guerra (ESG), Rio de Janeiro, RJ, Brasil. 